\title{
Article
}

\section{The Influence of Drying Temperature on Color Change of Hornbeam and Maple Wood Used as Surface and Inner Layers of Wood Composites}

\author{
Ivan Klement ${ }^{1, *} \mathbb{0}$, Peter Vilkovský ${ }^{1}$, Tatiana Vilkovská ${ }^{1}$, Kazimierz A. Orłowski $^{2} \mathbb{D}$, Jacek Barański ${ }^{3}$, \\ Daniel Chuchala $^{2}$ (D) and Aleksandra Suchta ${ }^{2}$ \\ 1 Department of Wood Technology, Faculty of Wood Sciences and Technology, Technical University in Zvolen, \\ T. G. Masaryka 24, 96001 Zvolen, Slovakia; peter.vilkovsky@tuzvo.sk (P.V.); t.hurakova21@gmail.com (T.V.) \\ 2 Institute of Manufacturing and Materials Technology, Faculty of Mechanical Engineering and Ship \\ Technology, Gdansk University of Technology, G. Narutowicza 11/12, 80-233 Gdansk, Poland; \\ korlowsk@pg.edu.pl (K.A.O.); daniel.chuchala@pg.edu.pl (D.C.); aleksandra.konopka@pg.edu.pl (A.S.) \\ 3 Energy Institute, Faculty of Mechanical Engineering and Ship Technology, Gdansk University of Technology, \\ G. Narutowicza 11/12, 80-233 Gdansk, Poland; jacek.baranski@pg.edu.pl \\ * Correspondence: klement@tuzvo.sk
}

check for updates

Citation: Klement, I.; Vilkovský, P.; Vilkovská, T.; Orłowski, K.A.; Barański, J.; Chuchala, D.; Suchta, A. The Influence of Drying Temperature on Color Change of Hornbeam and Maple Wood Used as Surface and Inner Layers of Wood Composites. Appl. Sci. 2021, 11, 10673. https:// doi.org/10.3390/app112210673

Academic Editor: Petar Antov

Received: 8 October 2021

Accepted: 5 November 2021

Published: 12 November 2021

Publisher's Note: MDPI stays neutral with regard to jurisdictional claims in published maps and institutional affiliations.

Copyright: (c) 2021 by the authors. Licensee MDPI, Basel, Switzerland. This article is an open access article distributed under the terms and conditions of the Creative Commons Attribution (CC BY) license (https:/ / creativecommons.org/licenses/by/ $4.0 /)$.

\begin{abstract}
The thermal treatment of wood changes its structure due to the degradation of wood polymers (cellulose, hemicellulose and lignin), so the physical properties of wood are either improved or degraded. Color changes apply not only to natural wood, but also to such wood composites for which some amount of glue is used in their construction (e.g., plywood, blockboard or laminboard). This article is focused on the analysis of hornbeam and field maple wood color changes influenced by drying temperature. Two types of drying modes were used: hot-air mode where the temperature of the drying environment was $60^{\circ} \mathrm{C}$, and high-temperature mode with a drying temperature of $120^{\circ} \mathrm{C}$. The drying mode was divided into two phases depending on the moisture content of the wood. The compared woods had similar values of color coordinates at the beginning of drying. During hot-air drying, the largest changes in color coordinates occurred during the first $24 \mathrm{~h}$. The total color difference between the color at the end and the beginning of drying was 7.3 for hornbeam and 11.1 for maple. The overall color difference between the compared woods was minimal. During high-temperature drying $\left(120^{\circ} \mathrm{C}\right)$, the color changes of the dried woods were more pronounced. In the case of maple wood, there was a very significant change in color and the value of $\Delta E^{*}$ was twice as high as for hornbeam. The total color difference between the color at the end and at the beginning of drying was 8.7 for hornbeam and 18.9 for maple.
\end{abstract}

Keywords: drying temperature; hornbeam; maple wood; color difference; composites

\section{Introduction}

The drying conditions and structure of wood can substantially affect the intensity of color change. Wood discoloration is a complex phenomenon, mainly affected by heat, light, and physiological and biochemical reactions. It is generally accepted that color changes increase as temperature increases. For that reason, deciduous wood species change color at lower temperatures compared to coniferous wood species [1,2]. Color, including texture and gloss, is one of the most important esthetic attributes of wood, and distinctively influences its commercial value [3,4]. Color varies widely across wood species and is primarily determined by the amount and chemical composition of the prevalent extractives [5]. The discoloration of wood due to kiln drying for set drying conditions is a remarkable problem and can affect the intensity of color change. The color of wood is primarily determined by the chemical compounds cellulose, hemicelluloses and lignin, as well as extractives [6,7]. 
The color change in the drying process is more pronounced in tree species, which are naturally pale in color. Maple and hornbeam also belong to the category of pale wood species. In these wood species, discoloration in the drying process is undesirable. This is in opposition to the effort to achieve the shortest possible drying time. Maple and hornbeam are among the tree species sensitive to color change in drying processes. We also include beech, birch and alder in this group of tree species.

High-temperature drying of wood is a special drying process. This process is characterized by a drying temperature above $100^{\circ} \mathrm{C}$. This special process is known for a very short drying time. As was also shown by research [7] focused on the change in hornbeam (Carpinus betulus L.) wood's properties, applying high-temperature drying results in a remarkable impact on color change as well. Research by these authors also found that equilibrium moisture content and color change of the hornbeam wood decreases with increasing temperature of the surrounding air. The smallest decrease was observed during the treatment at $170^{\circ} \mathrm{C}$ for $4 \mathrm{~h}$. Similar research [8] focused on the effect of moisture content $(E M C)$ and drying temperature on the color change of poplar and locust trees. Results showed that the color of locust trees did not change remarkably at $20^{\circ} \mathrm{C}$ in the moisture range below the fiber saturation point. Drying temperatures over $40^{\circ} \mathrm{C}$ resulted in the reduction of lightness, increased redness and decreased yellowness for locust trees. The color change of poplar trees was dominated by the loss of free water above the fiber saturation point. The color of wood changed remarkably only at $80^{\circ} \mathrm{C}$, in the bound-water range. The differences between heartwood and sapwood decreased as a consequence of moisture loss at all researched temperatures as the color coordinates of heartwood shifted towards the coordinates of sapwood. Comparing the reaction to moisture loss and temperature on the part of poplar and locust trees, the latter was more sensitive to heat. Other research [9] similarly discovered that treatment temperature had a more remarkable effect on color changes than treatment time.

Similarly, the work in [10] was focused on the analysis of beech wood with red false heart wood ( $F H W$ ) and mature wood $(M W)$ color changes by different methods. Research showed using high-temperature drying caused changes in the coordinates of the color space $\left(L^{*}, a^{*}, b^{*}\right)$. The biggest change in color was measured in the lightness coordinates $\left(L^{*}\right)$. Remarkable change was observed in mature wood after the drying process. Mature wood and red false heartwood had reached identical lightness $\left(L^{*}\right)$ at the end of high-temperature drying. Color change of beech wood (Fagus sylvatica L.) was also observed in another study [11] where the high-temperature drying process was used. Temperature inside the drying chamber during these experiments was $120^{\circ} \mathrm{C}$. The drying process revealed significant differences between color changes and measured values. Color changes were more noticeable in sapwood than in red heartwood, and measurements corroborated this observation In [12], where the combination of hot-air drying and high-temperature drying of birch timber was used, the color change of wood during the high-temperature drying of birch timber could be effectively reduced using hot-air drying during the early phase of the drying process. Drying conditions and methods can affect the intensity of color change [13], but so can conditions during the cutting process, such as cutting forces $[14,15]$ sawdust granularity [16,17], and physical properties [18-20].

This paper is focused on the comparison of color changes due to hot-air drying $\left(60^{\circ} \mathrm{C}\right)$ and high-temperature drying $\left(120^{\circ} \mathrm{C}\right)$. The aim of this study is to compare the color properties of hornbeam and maple using different chromaticity coordinates and to determine the effect of drying conditions and time on color change. This paper also compares the differences in hot-air and high-temperature drying kinetics.

\section{Material and Method}

Two wood species were used for experimental measurements: hornbeam (Carpinus betulus L.) and maple (Acer campestre L.) from forests belonging to the University Forest Enterprise of the Technical University in Zvolen, Slovakia. The samples were made from two hornbeam logs with a diameter of $29 \mathrm{~cm}$ and two maple logs with a diameter of $27 \mathrm{~cm}$ 
and a length of $150 \mathrm{~cm}$. The dimensions of the samples were $30 \mathrm{~mm}$ thickness, $120 \mathrm{~mm}$ width and $500 \mathrm{~mm}$ length; 30 samples were made from each wood species.

The oven-dry method was used to determine moisture content. Weighing was performed with an accuracy of $0.01 \mathrm{~g}$. The drying process to an absolutely dry condition was performed in a laboratory kiln at $103 \pm 2{ }^{\circ} \mathrm{C}$. The moisture content $(M C)$ was calculated using Equation (1) according to the norm [21].

$$
M C=\frac{m_{w}-m_{0}}{m_{0}} \cdot 100(\%)
$$

where $m_{w}$ is the weight of the wet sample (g) and $m_{0}$ is the weight of the absolutely dry sample (g).

Density in the absolutely dry state was determined for every sample with the content of red false heartwood and mature wood. The measurement was performed under laboratory conditions. Density in the absolutely dry state was calculated by Equation (2) according to the norm [22].

$$
\rho_{0}=\frac{m_{0}}{V_{0}}\left(\mathrm{~kg} \cdot \mathrm{m}^{-3}\right)
$$

where $m_{0}$ is the weight of oven-dried moisture samples $(\mathrm{kg})$ and $V_{0}$ is the volume of oven-dried moisture samples $\left(\mathrm{m}^{-3}\right)$.

\subsection{Drying Mode and Method}

Drying was performed in a laboratory oven from Memmert HCP 108 (Memmert $\mathrm{GmbH}+\mathrm{Co}$. KG, Schwabach, Germany). Two types of drying modes were used-hot-air mode, where the temperature of the drying environment was $60^{\circ} \mathrm{C}$, and high-temperature mode with a drying temperature of $120^{\circ} \mathrm{C}$. Each of these modes was divided into two phases depending on the moisture content of the dried wood. The parameters of the drying modes are given in Table 1.

\begin{tabular}{|c|c|c|c|c|c|c|}
\hline \multirow[b]{2}{*}{ Drying Mode } & \multicolumn{3}{|c|}{ 1. Phase $M C(\%) \geq F S P$} & \multicolumn{3}{|c|}{ 2. Phase $M C(\%)<F S P$} \\
\hline & $\begin{array}{c}\text { Temperature of } \\
\text { Environment } \\
\left({ }^{\circ} \mathrm{C}\right)\end{array}$ & $\begin{array}{c}\text { Psychometric } \\
\text { Difference }\left({ }^{\circ} \mathrm{C}\right)\end{array}$ & $\begin{array}{c}\text { Relative } \\
\text { Humidity of } \\
\text { Environment }(\%)\end{array}$ & $\begin{array}{c}\text { Temperature of } \\
\text { Environment } \\
\left({ }^{\circ} \mathrm{C}\right)\end{array}$ & $\begin{array}{c}\text { Psychometric } \\
\text { Difference }\left({ }^{\circ} \mathrm{C}\right)\end{array}$ & $\begin{array}{c}\text { Relative } \\
\text { Humidity of } \\
\text { Environment (\%) }\end{array}$ \\
\hline 60 & 60 & 2 & 91 & 60 & 12 & 52 \\
\hline 120 & 100 & 2 & 94 & 120 & - & - \\
\hline
\end{tabular}

Table 1. Used drying modes.

The last part of the drying schedule was cooling to approximately $20^{\circ} \mathrm{C}$. The average final moisture content was $10 \pm 1 \%$.

Based on the cited work [23], color measurements of all samples $(n=30)$ were recorded from the surface of wood specimens with a CR-10 Color Reader colorimeter (Konica Minolta Sensing, Inc., Sakura, Japan). Color measurement was performed every $24 \mathrm{~h}$. All color parameters are described below and were calculated using the following Equations (3)-(6).

\subsection{Color Difference $\Delta E^{*}$}

The scale of $\Delta E^{*}$ was classified according to the grading rules reported in Table 2 by [24]. All these properties (hue angle, color saturation and saturation) were measured with by [23].

$$
\Delta E^{*}=\sqrt{\left(L_{2}^{*}-L_{1}^{*}\right)^{2}+\left(a_{2}^{*}-a_{1}^{*}\right)^{2}+\left(b_{2}^{*}-b_{1}^{*}\right)^{2}}(-)
$$

where: $L_{1}{ }^{*}, a_{1}{ }^{*}$ and $b_{1}{ }^{*}$ are the values of color spectra before the drying process. $L_{2}{ }^{*}, a_{2}{ }^{*}$ and $b_{2}{ }^{*}$ are the values of color spectra after the drying process. 
Table 2. The scale of $\Delta E^{*}$ [24].

\begin{tabular}{ll}
\hline$\Delta E^{*}<0.2$ & No visible difference \\
$2>\Delta E^{*}>0.2$ & Small difference \\
$3>\Delta E^{*}>2$ & Color difference visible with high-quality screen \\
$6>\Delta E^{*}>3$ & Color difference visible with medium-quality screen \\
$12>\Delta E^{*}>6$ & High color difference \\
$\Delta E^{*}>12$ & Different colors \\
\hline
\end{tabular}

\subsection{Hue Angle- $h^{*}$}

Hue angle is one of the main properties of a color defined technically in the CIECAM02 model. The transformed $L^{*}, a^{*}$ and $b^{*}$ values are used in calculation of hue angle, chroma and lightness as well as chroma and hue differences, and these quantities are designated by a prime mark in the equations used [13]. Hue angle, ranging from 0 to 360 degrees in the Redness-Greenness $\left(a^{*}\right)$ and Yellowness-Blueness $\left(b^{*}\right)$ planes, is based on the concept of equal perceived difference. Equation (4) was used to determine hue angle.

$$
h^{*}=\tan ^{-1} \frac{b^{*}}{a^{*}}\left({ }^{\circ}\right)
$$

\subsection{Color Saturation- $C^{*}{ }_{a b}$}

Intensity of color was measured by color saturation [23]. For determining color saturation, Equation (5) was used.

$$
C_{a b}^{*}=\sqrt{a^{* 2}+b^{* 2}}
$$

\subsection{Saturation $-S_{a b}$}

The saturation [23] of a color is determined by a combination of light intensities, calculated with use of Equation (6). The most saturated color is achieved by using just one wavelength at a high intensity, such as in laser light.

$$
S_{a b}=\frac{C_{a b}^{*}}{\sqrt{C_{a b}^{* 2}+L^{* 2}}} \cdot 100(\%)
$$

\section{Results and Discussion}

The values of initial and final moisture contents, density in an absolutely dry state and drying times for individual wood species and drying modes are shown in Table 3.

The initial moisture content of the samples in both trees ranged from $66 \%$ to $70 \%$. The required final moisture content was reached by hot-air drying at a temperature of $60{ }^{\circ} \mathrm{C}$ (Figure 1). The drying time of the maple samples was $48 \mathrm{~h}$ shorter than that of hornbeam. During high-temperature drying $\left(120^{\circ} \mathrm{C}\right)$, the final moisture contents were remarkably lower than the required values for both wood species. This was due to a very rapid loss of moisture in the area below the fiber saturation point (Figure 2) when the drying temperature was raised to $120^{\circ} \mathrm{C}$. In this drying mode, the final time was not affected by the wood. Figures 1 and 2 show the drying curves for the individual wood

\begin{tabular}{|c|c|c|c|c|c|}
\hline Drying Mode & Samples & $\begin{array}{l}\text { Initial Moisture } \\
\text { Content } M C_{i}(\%)\end{array}$ & $\begin{array}{l}\text { Final Moisture } \\
\text { Content } M C_{f}(\%)\end{array}$ & $\begin{array}{c}\text { Density in Absolutely } \\
\text { Dry State }\left(\mathrm{kg} \cdot \mathrm{m}^{-3}\right)\end{array}$ & Drying Time (h) \\
\hline \multirow{2}{*}{60} & Hornbeam & $66.25 \pm 0.43$ & $9.00 \pm 0.28$ & $795.50 \pm 3.42$ & 384 \\
\hline & Maple & $65.54 \pm 0.64$ & $9.36 \pm 1.46$ & $579.92 \pm 4.81$ & 336 \\
\hline \multirow[b]{2}{*}{120} & Hornbeam & $68.14 \pm 0.22$ & $1.71 \pm 0.14$ & $799.10 \pm 2.90$ & 168 \\
\hline & Maple & $69.59 \pm 0.31$ & $2.19 \pm 0.07$ & $574.99 \pm 3.11$ & 168 \\
\hline
\end{tabular}
species and drying modes.

Table 3. Data about drying modes, initial and final moisture contents, density in absolutely dry state and drying times. 


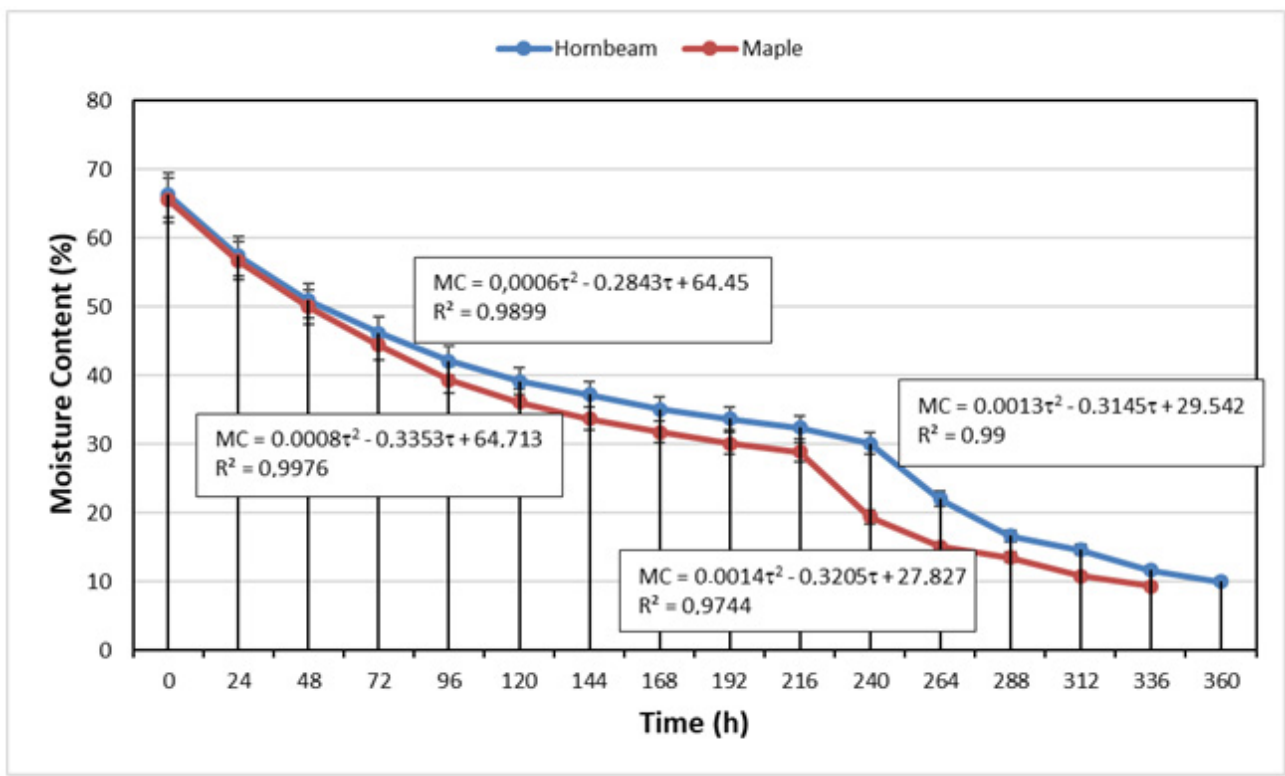

Figure 1. Drying curves for hot-air drying mode $\left(60^{\circ} \mathrm{C}\right)$.

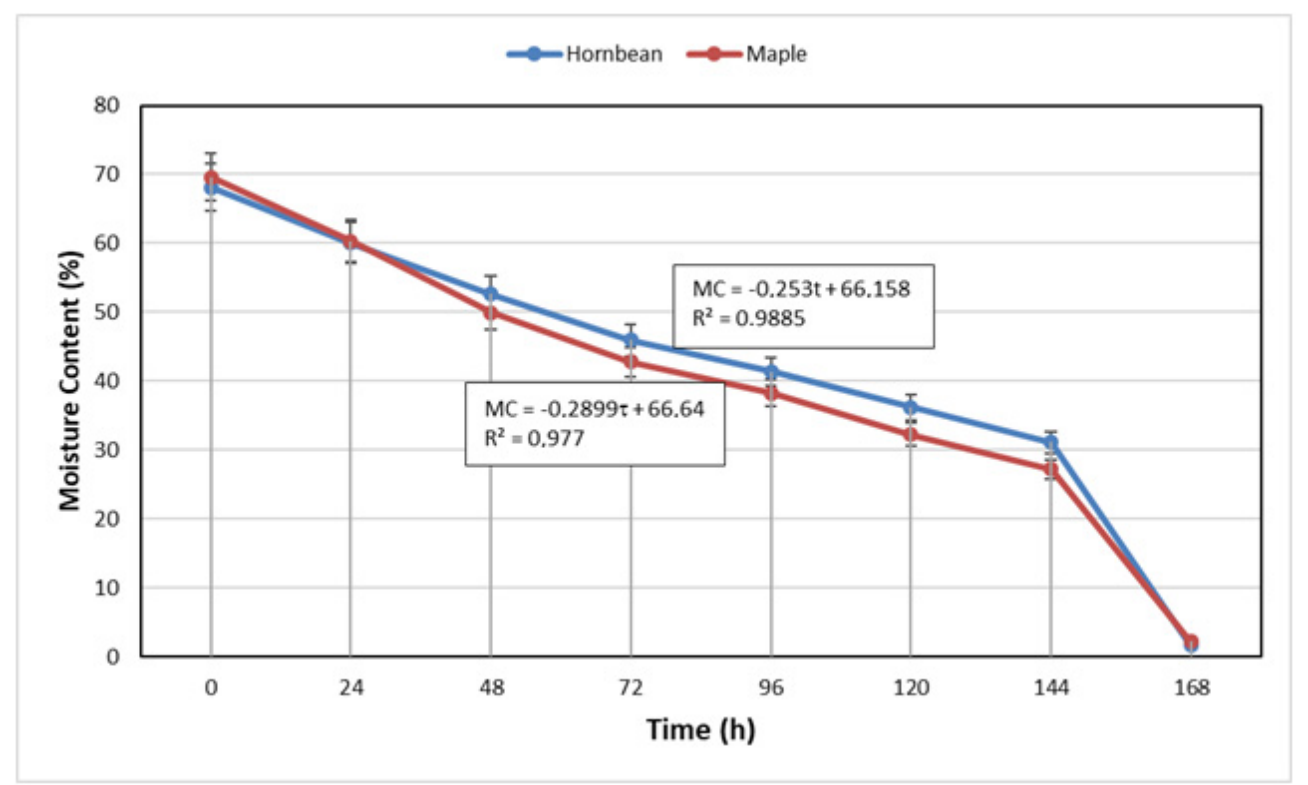

Figure 2. Drying curves for high-temperature drying mode $\left(120^{\circ} \mathrm{C}\right)$.

When comparing the drying curves between wood species, it can be seen that the maple samples dried faster than the hornbeam. According to [20], it could be that moisture losses are affected by different factors. According to the equation used to determine the moisture conductivity coefficient, density is the most influential factor, alongside the wood's structure and temperature. Therefore, the wood's density along with the treatment temperature, influence the drying curve. As the wood density increases, its moisture content conductivity decreases due to the relative reduction in the volume of the capillaries. This is the main reason for the slower drying of hornbeam. In high-temperature drying, this effect is compensated for by the increased drying temperature [20]. During hot-air drying (Figure 1), a difference was visible in both the area of free water and in the area of bound water. However, when the moisture content of the samples dropped below $50 \%$, the differences in moisture losses between the wood species increased. 
During high-temperature drying (Figure 2), a difference between the wood species in the first drying phase $(M C>F S P)$ was also visible. In the second phase of drying, when the temperature was raised to $120^{\circ} \mathrm{C}$, there was a very intense loss of moisture and both wood species reached a very low final humidity in $24 \mathrm{~h}$. The resulting drying time was the same.

The coordinates of the color space $L^{*}, a^{*}$ and $b^{*}$ were measured on the surface of the samples every $24 \mathrm{~h}$ and then the color difference $\Delta E^{*}$ was calculated according to Equation (3). The change of the color coordinate values and the calculated values of the color difference for the individual drying modes and wood species are graphically shown in Figures 3 and 4.

The compared wood species had similar values of color coordinates in the beginning of drying. Based on the $L^{*}$ coordinate, which expresses the brightness, we can characterize both wood species as light.

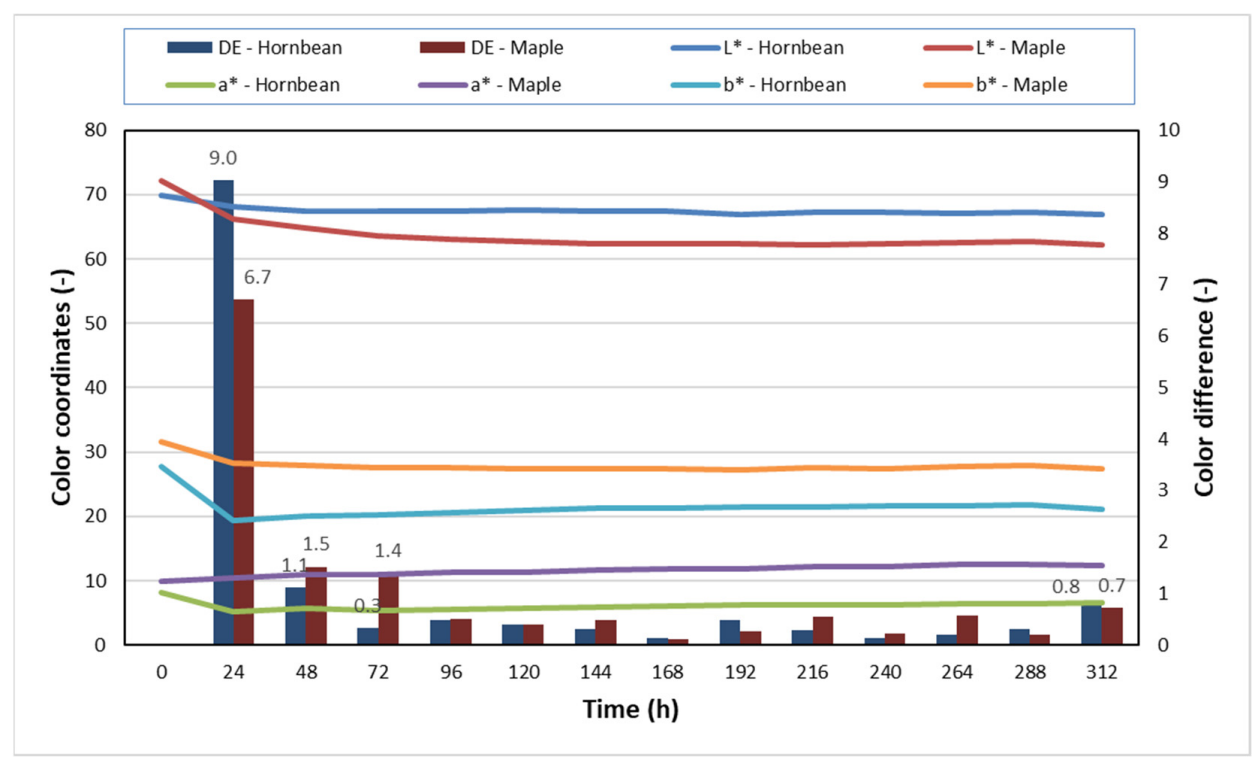

Figure 3. Change of color space coordinates and size of color difference during hot-air drying $\left(60^{\circ} \mathrm{C}\right)$.

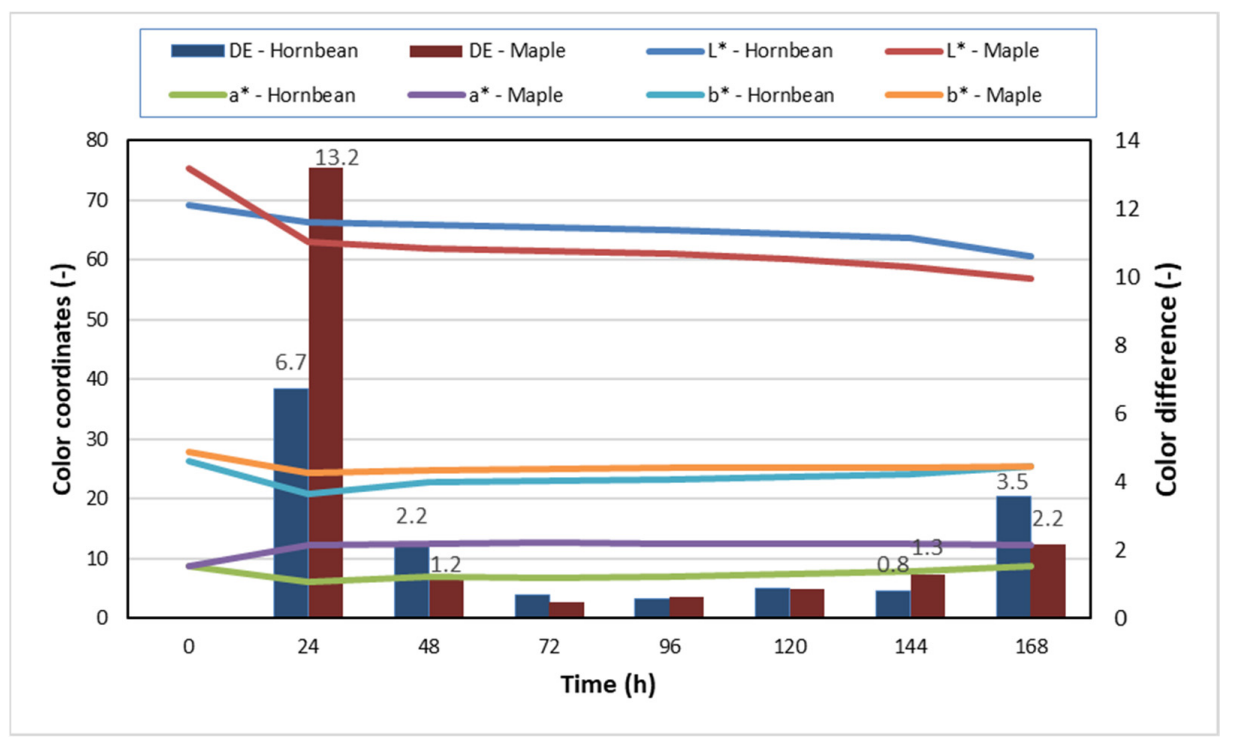

Figure 4. Change of color space coordinates and size of color difference during high-temperature drying $\left(120^{\circ} \mathrm{C}\right)$. 
During hot-air drying (Figure 3), the largest changes in color coordinates occurred during the first $24 \mathrm{~h}$. According to the values of the color difference in both wood species, a high color difference was found (Table 2). That is, the color changes were visible to the naked eye. For maple, the brightness value $\left(L^{*}\right)$ decreased remarkably and the samples darkened most significantly up to $144 \mathrm{~h}$ of drying. After this point, the brightness did not change. The brightness of hornbeam decreased less than that of maple. The total color differentiation between the color at the end and the beginning of the drying process was 7.3 for hornbeam and 11.1 for maple. For maple wood, the coordinate $a^{*}$ did not change during the drying process. The change in the coordinate $b^{*}$ was also smaller for maple than for hornbeam. The overall color difference between the compared wood species was minimal.

Similarly, in [8], they dried poplar wood and differences between $a^{*}$ values were found, but these differences decreased as moisture loss increased. The $b^{*}$ coordinates decreased significantly during the whole drying process. For temperatures of $60^{\circ} \mathrm{C}$ and $80^{\circ} \mathrm{C}$, the yellow hue values increased during drying.

The present observations $[8,9]$ showed that temperature had a much more remarkable impact on color changes than the duration of drying. These results agree with the work of [9-11], where a more remarkable effect of temperature than the time of drying on wood color change was confirmed.

During high-temperature drying $\left(120^{\circ} \mathrm{C}\right)$, the color changes in the dried wood species were more pronounced. Very pronounced changes in brightness, and therefore also the color of the samples, occurred in the first $24 \mathrm{~h}$ of drying. In contrast to hot-air drying, during the high-temperature drying there was a change in the coordinates of the color space even after raising the temperature to $120^{\circ} \mathrm{C}$, where the change in the brightness of the samples $\left(L^{*}\right)$ was visible. The values of color difference were also highest after $24 \mathrm{~h}$, where a very remarkable change of color (to a different color) occurred in maple wood and the value of $\Delta E^{*}$ was twice as high as in hornbeam wood. After raising the drying temperature to $120^{\circ} \mathrm{C}$, the color difference values increased. After high-temperature drying, the color difference was remarkable. Maple samples were remarkably darker than hornbeam samples. These results are also confirmed by [1,2], which state that the degradation of some chemical components of wood (hemicelluloses and lignin), depending on the wood species and the duration of action, occurs even at temperatures below $100{ }^{\circ} \mathrm{C}$.

In [9], $L^{*}$ decreased at all treatment temperatures, indicating that the color became darker. At $170{ }^{\circ} \mathrm{C}, L^{*}$ decreased steadily, and the maximum decrease in lightness was approximately $48.21 \%$ after $12 \mathrm{~h}$. Darkening of color was observed at $210{ }^{\circ} \mathrm{C}$ during the first $4 \mathrm{~h}$ and the darkest color occurred ( $L^{*}$ reduced by $64.23 \%$ ) after $12 \mathrm{~h}$.

The total color difference between the color at the end and the beginning of the drying process was 8.7 for hornbeam and 18.9 for maple. The change of individual coordinates of the color space was similar for the compared wood species. The difference was in the coordinate $a^{*}$, where in the first drying stage the value of this coordinate increased for maple wood, while it decreased for hornbeam. Table 4 shows the average values and basic statistical characteristics of the parameters $L^{*}, a^{*}$ and $b^{*}$ before and after drying.

The present observations are comparable with research $[6,11]$ that was focused on the analysis of beech wood with red false heartwood (FHW) and mature wood $(M W)$ color changes. When using high-temperature drying, it was discovered that the red false heartwood and mature wood had almost identical lightness $\left(L^{*}\right)$ at the end of the drying process. 
Table 4. Average values and basic statistical characteristics of the coordinates of the color space $L^{*}, a^{*}$ and $b^{*}$ for samples from hornbeam and maple.

\begin{tabular}{|c|c|c|c|c|c|c|c|c|c|}
\hline \multirow{2}{*}{\multicolumn{2}{|c|}{ Samples }} & \multirow{2}{*}{$\begin{array}{c}\text { Color } \\
\text { Coordinates }\end{array}$} & \multicolumn{3}{|c|}{ Before Drying } & \multicolumn{3}{|c|}{ After Drying } & \multirow[b]{2}{*}{ Count } \\
\hline & & & Mean & $\begin{array}{c}\text { Standard } \\
\text { Deviation }\end{array}$ & $\begin{array}{c}\text { Sample } \\
\text { Variance }\end{array}$ & Mean & $\begin{array}{c}\text { Standard } \\
\text { Deviation }\end{array}$ & $\begin{array}{c}\text { Sample } \\
\text { Variance }\end{array}$ & \\
\hline \multirow{6}{*}{$60{ }^{\circ} \mathrm{C}$} & \multirow{3}{*}{ Hornbeam } & $L^{*}$ & 69.8 & 1.503 & 2.259 & 67.0 & 3.277 & 10.737 & 30 \\
\hline & & $a^{*}$ & 8.3 & 0.747 & 0.558 & 6.6 & 0.610 & 0.372 & 30 \\
\hline & & $b^{*}$ & 27.7 & 0.361 & 0.130 & 21.1 & 0.946 & 0.896 & 30 \\
\hline & \multirow{3}{*}{ Maple } & $L^{*}$ & 66.1 & 1.842 & 3.393 & 62.2 & 0.587 & 0.344 & 30 \\
\hline & & $a^{*}$ & 12.7 & 0.669 & 0.448 & 12.4 & 0.541 & 0.293 & 30 \\
\hline & & $b^{*}$ & 33.0 & 1.129 & 1.275 & 27.3 & 0.158 & 0.025 & 30 \\
\hline \multirow{6}{*}{$120^{\circ} \mathrm{C}$} & \multirow{3}{*}{ Hornbeam } & $L^{*}$ & 69.3 & 0.533 & 0.284 & 60.6 & 1.373 & 1.886 & 30 \\
\hline & & $a^{*}$ & 8.7 & 0.507 & 0.257 & 8.8 & 0.567 & 0.322 & 30 \\
\hline & & $b^{*}$ & 26.3 & 0.706 & 0.498 & 25.4 & 0.083 & 0.007 & 30 \\
\hline & \multirow{3}{*}{ Maple } & $L^{*}$ & 75.3 & 0.816 & 0.666 & 56.8 & 1.202 & 1.444 & 30 \\
\hline & & $a^{*}$ & 8.7 & 0.422 & 0.178 & 12.2 & 0.446 & 0.199 & 30 \\
\hline & & $b^{*}$ & 27.9 & 0.501 & 0.251 & 25.5 & 0.620 & 0.385 & 30 \\
\hline
\end{tabular}

From the measured data it can be seen that changes in the coordinates of the color space were detected in high-temperature drying $\left(120^{\circ} \mathrm{C}\right)$ of maple wood. Calculated values of standard deviation and sample variance confirmed a small variance of the measured values of the color space coordinates from the average value. Thirty measurements of $L^{*}, a^{*}$ and $b^{*}$ coordinates were made on each sample. The calculated values of hue angle, color saturation and saturation are given in Table 5 .

The hue angle values of both groups of samples were approximately the same before drying. Maple wood exhibited lower values. During drying, there was a remarkable decrease in the value of the hue angle towards the red-brown color of maple wood during high-temperature drying. Similar results were observed in [12], where a remarkable color change in birch samples was confirmed. During the drying of mature wood $(M W)$, there was a noticeable decrease in the hue angle towards the red-brown color. It changed from $72^{\circ}$ before drying to $57.4^{\circ}$ after drying on $M W$. As also shown in [12], the combination mode (hot-air drying and high-temperature drying) could remarkably reduce the color change in the early phase of drying process.

Table 5. Calculated values of hue angle, color saturation and saturation in the hot-air drying $\left(60^{\circ} \mathrm{C}\right)$ and high-temperature drying $\left(120^{\circ} \mathrm{C}\right)$ processes.

\begin{tabular}{|c|c|c|c|c|c|}
\hline \multicolumn{2}{|c|}{ Samples } & Process & $\begin{array}{l}\text { Hue Angle } \\
\qquad h^{*}\left({ }^{\circ}\right)\end{array}$ & $\begin{array}{c}\text { Color } \\
\text { Saturation } C^{*}{ }_{a b}\end{array}$ & $\begin{array}{c}\text { Saturation } \\
S_{a b}(\%)\end{array}$ \\
\hline \multirow{4}{*}{$60^{\circ} \mathrm{C}$} & \multirow{2}{*}{ Hornbeam } & Before drying & 73.4 & 28.9 & 38.2 \\
\hline & & After drying & 72.7 & 22.1 & 31.4 \\
\hline & \multirow{2}{*}{ Maple } & Before drying & 69.0 & 35.3 & 47.2 \\
\hline & & After drying & 65.5 & 30.0 & 43.5 \\
\hline \multirow{4}{*}{$120^{\circ} \mathrm{C}$} & \multirow{2}{*}{ Hornbeam } & Before drying & 71.7 & 27.7 & 37.2 \\
\hline & & After drying & 71.0 & 26.8 & 40.5 \\
\hline & \multirow{2}{*}{ Maple } & Before drying & 72.6 & 29.2 & 36.2 \\
\hline & & After drying & 64.5 & 28.3 & 44.5 \\
\hline
\end{tabular}

There were minimal differences in hot-air drying. There were minimal differences in hot-air drying. The values of $S_{a b}$ and $C_{a b}^{*}$ decreased in both wood species during hot-air drying $60^{\circ} \mathrm{C}$ (Table 5). During high-temperature drying $\left(120^{\circ} \mathrm{C}\right)$ the values increased. A more significant increase was seen in the maple wood. Color changes of hornbeam and maple during hot-air drying $\left(60^{\circ} \mathrm{C}\right)$ and high-temperature drying $120^{\circ} \mathrm{C}$ are shown in Figure 5. A similar result was evident in [19], where a red coloration of maple wood was discovered when it was exposed to high temperatures. 

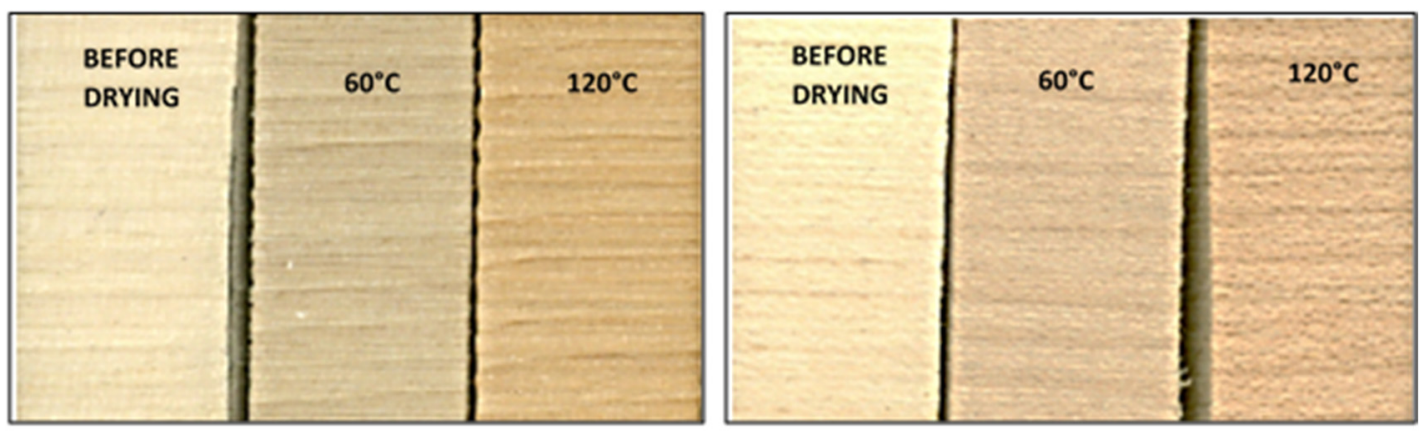

Figure 5. Color change in hornbeam and maple during hot-air drying $\left(60^{\circ} \mathrm{C}\right)$ and high-temperature $\operatorname{drying}\left(120^{\circ} \mathrm{C}\right)$.

\section{Conclusions}

- During hot-air drying $\left(60^{\circ} \mathrm{C}\right)$, maple samples dried faster than hornbeam samples. The difference in drying times of wood species is directly proportional to their density.

- During high-temperature drying, maple samples were dried faster in the first drying section $(M C>F S P)$, but after raising the temperature of the drying environment to $120^{\circ} \mathrm{C}$, the resulting times for both woods were identical.

- For maple wood, there were remarkable changes in the coordinates of the color space $L^{*}, a^{*}$ and $b^{*}$ with both methods of drying. At a maximum drying temperature of $60{ }^{\circ} \mathrm{C}$, the most remarkable change in coordinates occurred during the first $24 \mathrm{~h}$ of drying. For maple, the brightness value $L^{*}$ decreased remarkably, but the $a^{*}$ coordinate hardly changed. The change in the $b^{*}$ coordinate was also smaller for maple than for hornbeam. The color difference between the compared woods at a drying temperature of $60^{\circ} \mathrm{C}$ was minimal. The total color difference between the color at the end and at the beginning of drying was 7.3 for hornbeam and 11.1 for the maple.

- During high-temperature drying $\left(120^{\circ} \mathrm{C}\right)$, the color changes of the dried woods were more pronounced. There was a remarkable change at the beginning of drying, but also after raising the temperature to $120^{\circ} \mathrm{C}$, where there was mainly a change in the coordinate of $L^{*}$. The maple samples were darker than the hornbeam samples, likely due to enhancement of oxidation during high-temperature drying. The total color difference between the color at the end and the beginning of the drying was 8.7 for hornbeam and 18.9 for maple. The color change was visible to the naked eye.

- A remarkable change in color of the maple samples during high-temperature drying was also confirmed by the values of hue angle, color saturation and saturation in individual measurement sections. During the drying of maple samples, there was a remarkable decrease in the value of the hue angle towards a red-brown color. The change was $8.1^{\circ}$ for maple and $0.7^{\circ}$ for hornbeam.

- The $S_{a b}$ and color saturation values decreased in both wood species during hot-air drying $\left(60^{\circ} \mathrm{C}\right)$. A more significant reduction in $S_{a b}$ was observed in hornbeam, a difference of $6.8^{\circ}$. During high-temperature drying $\left(120^{\circ} \mathrm{C}\right)$ the values increased. There was a more remarkable increase in maple wood $\left(8.3^{\circ}\right)$.

- There was a visible color change in both monitored wood species due to the drying process. An effect of the temperature of the drying medium in combination with the humidity of the dried wood was confirmed. Differences were observed in the brightness and color shade. These differences are due to the chemical composition of individual trees and thus also to different hydrolysis reactions due to the interaction of temperature and humidity.

Wood color is one of the most attractive properties for the modern wood industry. However, during processing, especially during drying, the wood may undergo color changes. The color change can be regulated by drying conditions with changing wood moisture content. Such color changes apply not only to natural wood, but also wood 
composites such as plywood, blockboard or laminboard, where thin and quality surface layers are made by rotary peeling of veneer, including both hornbeam and maple logs.

Author Contributions: Conceptualization, I.K., P.V. and T.V.; methodology, P.V.; software, P.V. and I.K.; validation P.V. and I.K.; formal analysis, P.V.; investigation, P.V.; resources, T.V., K.A.O. and D.C.; data curation, I.K. and J.B.; writing—original draft preparation, P.V.; writing-review and editing, T.V. and A.S.; visualization, P.V., A.S. and D.C.; supervision, I.K.; project administration, I.K.; funding acquisition, P.V. All authors have read and agreed to the published version of the manuscript.

Funding: This research was funded by the Slovak Research and Development Agency under contract no. SK-PL-18-0052 and contract no. APVV-19-0269.

Institutional Review Board Statement: Not applicable.

Informed Consent Statement: Not applicable.

Data Availability Statement: The data presented in this study are available on request from the corresponding author.

Acknowledgments: This research was funded by the Slovak Research and Development Agency under contract no. SK-PL-18-0052 and contract no. APVV-19-0269. The authors would like to acknowledge the Polish National Agency for Academic Exchange (NAWA, Warsaw, Poland) for financial support within the bilateral project No. PPN/BIL/2018/1/00162.

Conflicts of Interest: The authors declare no conflict of interest.

\section{References}

1. Torres, S.; Jomaa, S.; Marc, W.; Puiggali, J.F. Causes of color changes in wood during drying. For. Stud. China 2010, 12, 167-175. [CrossRef]

2. White, R.H.; Dietenberger, M. Wood Products: Thermal Degradation and Fire. In Encyclopedia of Materials: Science and Technology; Elsevier Science Ltd.: Madison, WI, USA, 2001; pp. 9712-9716. [CrossRef]

3. Papp, E.A.; Csiha, C.; Valent, J. Colour change of some wood species during artificial xenon radiation. Obuda Univ. e-Bull. 2012, 3, 89-97.

4. Pandey, K.K.A. Note on the influence of extractives on the photo-discoloration and photo-degradation of wood. Polym. Degrad. Stabil 2005, 87, 375-379. [CrossRef]

5. Hon, S.N.D.; Shiraishi, N. Wood and Cellulosic Chemistry; Woodand Cellulosic Chemistry Marcel Dekker: New York, NY, USA, 2001; pp. 385-442.

6. Klement, I.; Marko, P. Colour changes of beech wood (Fagus sylvatica L.) during high temperature drying process. Wood Res. 2009, $54,45-54$.

7. Gündüz, G.; Aydemir, D. Some Physical Properties of Heat-Treated Hornbeam (Carpinus betulus L.) Wood. Drying Technol. 2009, 27, 714-720. [CrossRef]

8. Németh, R.; Ott, Á.; Takáts, P.; Bak, M. The effect of moisture content and drying temperature on the colour of two poplars and Robinia wood. BioResources 2013, 8, 2074-2083. [CrossRef]

9. Gündüz, G.; Aydemir, D.; Korkut, S. The Effect of Heat Treatment on Some Mechanical Properties and Color Changes of Uludag Fir Wood. Drying Technol. 2010, 28, 249-255. [CrossRef]

10. Klement, I.; Vilkovská, T. Color Characteristics of Red False Heartwood and Mature Wood of Beech (Fagus sylvatica L.) Determining by Different Chromacity Coordinates. Sustainability 2019, 11, 690. [CrossRef]

11. Barański, J.; Klement, I.; Vilkovská, T.; Konopka, A. High temperature drying process of beech wood (Fagus sylvatica L.) with different zones of sapwood and red false heartwood. BioResources 2017, 12, 1861-1870. [CrossRef]

12. Möttönen, V.; Kärki, T. Effect of Drying Force on Birch Wood Colour Change during High Temperature Drying. Baltic For. 2007, 13, 126-130.

13. Konopka, A.; Baranski, J.; Orlowski, K.A.; Chuchala, D. The effect of drying intensity on the color changes of pine wood (Pinus Sylvestris L.). Trieskove Beztrieskove Obrabanie Dreva 2020, 12, 79-84.

14. Konopka, A.; Chuchala, D.; Orlowski, K.A.; Tatiana, V.; Klement, I. The effect of beech wood (Fagus sylvatica L.) steaming process on the colour change versus depth of tested wood layer. Wood Mater. Sci. Eng. 2021. [CrossRef]

15. Chuchala, D.; Ochrymiuk, T.; Orlowski, K.A.; Lackowski, M.; Taube, P. Predicting cutting power for band sawing process of pine and beech wood dried with the use of four different methods. BioResources 2020, 15, 1844-1860. [CrossRef]

16. Chuchala, D.; Sandak, J.; Orlowski, K.A.; Muzinski, T.; Lackowski, M.; Ochrymiuk, T. Effect of the Drying Method of Pine and Beech Wood on Fracture Toughness and Shear Yield Stress. Materials 2020, 13, 4692. [CrossRef]

17. Rogozinski, T.; Chuchala, D.; Pedzik, M.; Orlowski, K.A.; Dzurenda, L.; Muzinski, T. Influence of drying mode and feed per tooth rate on the fine dust creation in pine and beech sawing on a mini sash gang saw. Eur. J. Wood Wood Prod. 2021, 79, 91-99. [CrossRef] 
18. Orłowski, K.A.; Chuchała, D.; Muziński, T.; Barański, J.; Banski, A.; Rogoziński, T. The effect of wood drying method on the granularity of sawdust obtained during the sawing process using the frame sawing machine. Acta Fac. Xylologiae Zvolen 2019, 61, 83-92. [CrossRef]

19. Gao, J.; Zhang, B.; Chang, J. Induced discoloration of buerger maple during drying process. For. Stud. China 2004, 6, 50-55. [CrossRef]

20. Sergovskij, S.P. Hydrotermická Úprava Dreva a Sušenie Dreva (Hydrothermal Treatment of Wood and Drying of Wood), 1st ed.; ALFA Publishing of Technical and Economic Literature: Bratislava, Slovakia, 1977; p. 402.

21. STN EN 49 0103. Determination of Moisture Content of the Physical Mechanical Tests; Slovak Standards Institute: Bratislava, Slovakia, 1979.

22. STN 490 108. Wood. Determination of Density; Slovak Standards Institute: Bratislava, Slovakia, 1993.

23. Schanda, J. Colorimetry: Understanding the CIE System; John Wiley \& Sons: Hoboken, NJ, USA, 2007; pp. 445-449, ISBN 9780470049044.

24. Cividini, R.; Travan, L.; Allegretti, O. White Beech: A Tricky Problem in Drying Process; NARDI Srl: Siena, Italy, 2007. Available online: www.ivalsa.cnr.it/ISCHP07/CividiniTravanAllegretti.pdf (accessed on 27 January 2019). 